\title{
Possibility of the Implementation of the Principle of Sustainable Development in the Sphere of Coal Processing
}

\author{
Ludmila Butuzova, Oksana Turchanina, Shwan Shakir, Gennadij Butuzov \\ Donetsk National Technical University, Donetsk, Ukraine \\ Achim Bechtel \\ University of Leoben, Vienna, Austria \\ Antonio Castelbranco \\ Lisbon Technical University, Lisbon, Portugal
}

\begin{abstract}
High-sulphur coals processing generates a great number of pollutant substances in atmosphere. This study was undertaken to obtain more definite information about the composition of sulphur coal extracts, i.e., on the quality and quantity of dormant Volatile Organic Emissions (VOCs). Analysis of the liquid products was carried out by different protocols of extraction, adsorption chromatography, and GC/MS identification. It should be pointed out that the basic components of coal extracts are polyaromatic hydrocarbons, sulfur-containing compounds and phenols act as a basic factor of environment pollution with carcinogenic products. The complex treatment of these components will permit not only to obtain some valuable chemical products, but also to improve the ecology in the industrial regions.
\end{abstract}

Keywords: coal, extracts, organic emissions, polyaromatic hydrocarbons, GC/MS

\section{Introduction}

The sustainable development concept which from the beginning of 90th year dominated in the world community has been officially declared in the document "Global program of actions - the summons for 21st century". This ideology assumes change of priorities at the decision of ecologic-economic commitments.

High consumption of the energy and fuels in industry is remarkable in high production of polluting substances which have a great influence not only for human health but also for the vegetation and ecosystem balance (Mastral, Callen, Murillio, Garcia, \& Vinas, 1999; Lavrieux et al., 2011).

The major part of wastes generated by the industry comes from coal mining, coking plants, power generation, and metallurgy. The considerable part of these waste materials is ejected to atmosphere and groundwater or stored in the conditions of limited area creating the contamination of the environment. During

Ludmila Butuzova, Dr.Sc., Full Professor, Head of Chemical Technology of Fuel Department, Donetsk National Technical University.

Oksana Turchanina, Docent, Ph.D., Chemical Technology of Fuel Department, Donetsk National Technical University.

Shwan Shakir, Postgraduate, Chemical Technology of Fuel Department, Donetsk National Technical University.

Gennadij Butuzov, Docent, Ph.D., Labor Protection and Aerology Department, Donetsk National Technical University.

Achim Bechtel, Docent, Ph.D., Department of Applied Geosciences \& Geophysics, University of Leoben.

Antonio Castelbranco, Docent, Ph.D., Faculty of Architecture, Lisbon Technical University.

Correspondence concerning this article should be addressed to Ludmila Butuzova, Donetsk National Technical University, 58, Artema str., 83001, Donetsk, Ukraine. E-mail: ludmila.lfb@yandex.ua. 
coal processing basic harmful pollutants are emitted: $\mathrm{SO}_{\mathrm{x}}, \mathrm{NO}_{\mathrm{x}}, \mathrm{CO}_{\mathrm{x}}$ (in oxidant medium) or $\mathrm{H}_{2} \mathrm{~S}, \mathrm{NH}_{3}$ (in reducing-agent medium), effluvial and toxic organic compounds, dibenzodioxins, dibenzofurans and oth (Mastral, Callen, \& Garcia, 2000a; Mastral, Callen, Garcia, \& Lopez, 2000b).

A pollutant emission depends on the heteroatoms content in the raw material and conditions of coal processing.

Within volatile organic emissions, polycyclic aromatic hydrocarbons (PAHs) and their derived compounds are the most carcinogenic. PAHs can get into water and soil being assimilated by the plants, animals, fish, and human body (Mastral, Callen, \& Garcia, 2000b).

At present, European Union legislation establishes limit values for concentrations of sulphur, nitrogen, and carbon oxides, but there is a lack of similar legislation concerning organic compounds emission.

Every year Ukrainian coking plants produce a significant quantity of following waste materials: phenol-containing sewage (30\%-40\% df), emission into atmosphere (0.7\%-0.8\% df), and wastes of chemical department $(0.10 \%-0.15 \% \mathrm{df})$.

The pollutant emission has increased considerably in recent years to the increased use of low-quality coals with high content of sulfur and oxygen.

A particular characteristic of seams from Donets coal basin is the occurrence of high- and low-sulfur coals, of the same rank differing by some physicochemical properties (The Donetsk Coal Chemistry Research Institute, 1972). These differences are due to specified genetic types formed in alluvial or marine depositional environments during diagenesis processes. High-sulfur coals creation on biochemical stage occurred in high reduced environment with sea water and the presence of anaerobic bacteria (Stach et al., 1975; Taylor et al., 1998).

Previously it was investigated the composition and properties of the Donets coals with different content of sulphur and oxygen (Bechtel, Butuzova, \& Turchanina, 2002; Butuzova, Isaeva, Turchanina, \& Krzton, 2002; Butuzova, 2004; Butuzova, Minkova, Safin, Marinov, \& Stamenova, 2005; Butuzova, Marinov, Minkova, Safin, Stefanova, \& Stamenova, 2005; Butuzova, Bechtel, Turchanina, Safin, Butuzov, \& Isaeva, 2005; Butuzova et al., 2007; Minkova, Butuzova, Marinov, \& Safin, 2004; Marinov, Minkova, Stefanova, \& Butuzova, 2000). It was demonstrated that they distinguished in their behavior in the pyrolysis processes. A high reactivity for sulphur coals in coking and lacing processes was indicated (Butuzova, Minkova, Safin, Marinov, \& Stamenova, 2005). Pyrolysis of low rank sulphur coals results in a 1.8-2.0 fold acceleration in the maximal gas evolution rate.

The reactions of -S- and -O- containing groups affect the thermodestruction processes resulting in variations in the yield and composition of liquid, solid, and gaseous products and the degree of coal organic matter (COM) conversion. The semi-coking of low rank sulphur samples produce a substantially higher yield of tar and higher content of aliphatic hydrocarbons in semi-coking gas and tar than low-reduced coals (LRC) (Butuzova, Safin, Marinov, Yaneva, Turchanina, \& Butuzov, 2009; Butuzova, Marinov, Minkova, Safin, Stefanova, \& Stamenova, 2005). So, low rank reduced coals (RC) may be suitable raw material for oil generation (Petersen \& Nytoft, 2006).

Sulphur- and oxygen-containing groups take part in the processes of radical formation and recombination during thermal and thermochemical destruction of caking and noncaking coals. They promote the breakdown of lateral chains and increase the amount of the paramagnetic centers (Butuzova, Rozhkov, Makovskyi, Rozhkova, \& Butuzov, 2009), which plays one of the most important role for pyrolysis way and composition of products 
(Butuzova, Krzton, Saranchuk, \& Isaeva, 1994; Butuzova \& Krzton, 2001).

According to aforementioned data, it could be concluded that environmental protection requires increased recycling of the nonbiodegradability and toxic organic wastes and further waste reduction. Methods for the elimination of wastes such as burial, incineration, and biodecomposition burial are commonly used, but in the case of coal tars they are ineffective.

The aim of the present study is to investigate the composition of extracts from high- and low-sulphur coals of the different rank and to study organic emissions as a function of the coal sulfur content.

\section{Materials and Methods}

Pairs of the isometamorphic Donets coals homogeneous by their petrographic composition, but formed under reductive (RC) or less reductive conditions (LRC) and different by their sulphur content accordingly were used as objects of research. It was coals of D-Grade and J-Grade according to Ukrainian classification (see Table 1).

Table 1

Proximate and Ultimate Analyses of Parent Coals

\begin{tabular}{|c|c|c|c|c|c|c|c|c|c|c|c|c|c|c|}
\hline No. & $\begin{array}{l}\text { Coal } \\
\text { grade }\end{array}$ & Type & $\begin{array}{l}\text { Coal mine, } \\
\text { coal seam }\end{array}$ & $\begin{array}{l}\mathrm{R}_{\mathrm{o}} \\
(\%)\end{array}$ & $\begin{array}{l}\mathrm{W}^{\mathrm{a}} \\
(\mathrm{wt} \%)\end{array}$ & $\begin{array}{l}\mathrm{A}^{\mathrm{d}} \\
(\mathrm{wt} \%)\end{array}$ & $\begin{array}{l}\mathrm{V}^{\text {daf }} \\
(\mathrm{wt} \%)\end{array}$ & $\begin{array}{l}\mathrm{C}^{\text {daf }} \\
(\mathrm{wt} \%)\end{array}$ & $\begin{array}{l}\mathrm{H}^{\mathrm{daf}} \\
(\mathrm{wt} \%)\end{array}$ & $\begin{array}{l}\mathrm{N}^{\mathrm{daf}} \\
(\mathrm{wt} \%)\end{array}$ & $\begin{array}{l}\mathrm{S}_{\mathrm{t}}^{\mathrm{d}} \\
(\mathrm{wt} \%)\end{array}$ & $\begin{array}{l}\mathrm{S}_{\mathrm{s}}^{\mathrm{d}} \\
(\mathrm{wt} \%)\end{array}$ & $\begin{array}{l}\mathrm{S}_{\mathrm{p}}{ }^{\mathrm{d}} \\
(\mathrm{wt} \%)\end{array}$ & $\begin{array}{l}\mathrm{S}_{\mathrm{o}}^{\text {daf }} \\
(\mathrm{wt} \%)\end{array}$ \\
\hline 1 & $\mathrm{D}$ & LRC & Cheluskintsev, $1_{4}$ & 0.71 & 0.8 & 2.4 & 35.6 & 79.3 & 4.94 & 2.32 & 2.17 & 0.04 & 0.11 & 2.07 \\
\hline 2 & $\mathrm{D}$ & LRC & Trudovskaya, $1_{4}$ & 0.55 & 1.0 & 1.6 & 37.3 & 78.4 & 4.95 & 1.90 & 1.05 & 0.04 & 0.17 & 0.85 \\
\hline 3 & $\mathrm{~J}$ & LRC & Gagarina, $\mathrm{m}^{3}$ & 1.01 & 1.2 & 3.7 & 28.7 & 87.4 & 5.06 & 1.56 & 0.70 & 0.06 & 0.03 & 0.61 \\
\hline 4 & $\mathbf{J}$ & LRC & Zasyad'ko, $1_{4}$ & 1.18 & 1.4 & 2.6 & 31.6 & 87.8 & 5.16 & 1.95 & 1.09 & 0.01 & 0.24 & 0.84 \\
\hline $1^{1}$ & $\mathrm{D}$ & $\mathrm{RC}$ & Ukraine, $\mathrm{k}_{8}$ & 0.57 & 1.5 & 9.9 & 41.8 & 77.9 & 5.30 & 2.10 & 2.87 & 0.11 & 0.80 & 2.18 \\
\hline $2^{1}$ & $\mathrm{D}$ & $\mathrm{RC}$ & Trudovskaya, $\mathrm{k}_{8}$ & 0.49 & 0.9 & 4.6 & 46.2 & 76.1 & 5.43 & 1.97 & 5.85 & 0.05 & 0.71 & 5.34 \\
\hline $3^{1}$ & $\mathrm{~J}$ & $\mathrm{RC}$ & Gagarina, $\mathrm{m}_{4}^{0}$ & 0.96 & 0.8 & 12.2 & 35.6 & 83.6 & 4.88 & 1.64 & 3.75 & 0.05 & 2.41 & 1.29 \\
\hline $4^{1}$ & $\mathrm{~J}$ & $\mathrm{RC}$ & Zasyad'ko, $1_{4}$ & 0.96 & 0.8 & 2.7 & 31.7 & 87.3 & 5.23 & 1.48 & 2.81 & 0.02 & 1.14 & 1.65 \\
\hline
\end{tabular}

The samples studied include four pairs ("RC-LRC") of non-coking coals of D-Grade and coking coals of J-Grade, according to Ukrainian classification. Their geological age is Middle Carboniferous. They have uniform petrographic composition: $80 \%-89 \%$ of vitrinite, 3\%-8\% of liptinite, and 5\%-14\% of intertinite. Each pair of samples of the low-reduced and reduced coals was collected from neighbouring coal seams (separated by less than $100 \mathrm{~m}$ ). Limestone layers at the top of the coal seams and finely crystalline pyrite presence were reliable signs of a reduced type of Donets coals. In addition, the content of microlithotypes with finely dispersed pyrite (carbopyrite) was identified. It is also an indicator of reduced and low-reduced type of coals.

The proximate, ultimate, and petrographic analysis of samples, including total sulfur (St), organic (So), pyrite (Sp), and sulphate (Ss) were determined by using standard methods (GOST 9414.3-93, 12113-94, 27314-91, 11022-95, 8606-93, 6382-91, 2408.1-95, 2408.3-95). The total organic carbon content was measured on a Leco carbon analyzer on the samples pre-treated with concentrated hydrochloric acid and calculated on a dry and ash-free basis $\left(\mathrm{C}^{\mathrm{daf}}\right.$, wt $\%$ of the sample).

To determine the most expedient way of sulfur coals technological employment it is important to establish the relationship between the sulfur compounds in Coal Organic Matter (COM) and the basic properties of solid fuels. Statistical methods are applied to the data set derived from the analysis permitting a quantitative description of the effect of the contribution of sulfur into the formation of coal properties. The statistical analysis was performed using the Microsoft Excel and Origin 6.1 software package. 
Qualitative characteristics of the Donetsk Basin mined coal seams given in the reference book on the quality of various rank coals and anthracites of the Donetsk and Lviv-Volyn Basins (Catalogue 1972) were used as the data base. All the samples of investigated coals mentioned in the reference book have been selected. From this selection 100 samples characterized by the proximate and ultimate analysis, mainly, the following indices: the total sulphur content (of the seam sample), the volatile matter yield (wt\%), the plastometric indicator, i.e., $y$, the elemental composition (i.e., the carbon, hydrogen, sulphur, the total nitrogen and oxygen contents) and the atomic ratios of the individual elements to carbon were used for the statistical analysis. Moreover, the reference data were supplemented by the results of the analysis of two couples of freshly-sampled long-flame coals and two couples of freshly-sampled J-Grade coals of different genetic types (see Table 1).

Statistical methods help us to see that closeness of the statistical connection between the yield of volatile matters and the content of organic sulphur decreases with metamorphism in the transition from D-grade coals to J-grade coals.

The thermal behaviour of coals was studied by classical Fisher method $\left(520^{\circ} \mathrm{C}\right)$.

Extraction, liquid chromatography and gas chromatography-mass spectrometry (GC-MS) of the saturated and aromatic hydrocarbon fractions were used to the separation and identification of coal extracts.

The pulverised samples (about $7 \mathrm{~g}$ ) were extracted using dichloromethane in a Dionex ASE 200 accelerated solvent extractor at $75{ }^{\circ} \mathrm{C}$ and 50 bar. The solvent was evaporated in a Zymark TurboVap 500 closed sell concentrator. Then the asphaltenes were precipitated from $n$-hexane-dichloromethane solution (80:1 v/v) and separated by centrifugation.

The medium-pressure liquid chromatography (Köhnen-Willsch) was used for the separation of the $n$-hexane-soluble fraction of coal organic matter into saturated, aromatic hydrocarbons and polar heterocompounds.

Gas chromatograph was equipped with a 25-m DB-1 fused silica capillary column (diameter $0.25 \mathrm{~mm}$ ) and coupled to a Finnigan MAT GCQ ion trap mass spectrometer. The oven temperature was programmed from $70{ }^{\circ} \mathrm{C}$ to $300{ }^{\circ} \mathrm{C}$ at a rate of $4{ }^{\circ} \mathrm{C} \mathrm{min}{ }^{-1}$ followed by an isothermal period of $15 \mathrm{~min}$.

Helium was the carrier gas. The samples ionisation in mass spectrometer was achieved by the electron impact $(70 \mathrm{eV})$ and a scan range of 50-650 daltons ( $0.7 \mathrm{~s}$ total scan time). Data were processed with a Finnigan data system. Identification of the individual compounds was accomplished by their retention times in the total ion current chromatogram and by comparison of the mass spectra with those of published data (Bechtel, Butuzova, \& Turchanina, 2002).

Relative percentages and absolute concentrations of the compounds in the saturated and aromatic fractions were calculated using peak areas from the gas chromatograms in relation to that of internal standards. The concentrations were normalised to the $\mathrm{C}^{\mathrm{daf}}$ content in the sample.

\section{Results and Discussions}

The statistical dependence between the organic sulfur content and the main classification parameter-volatile matter yield has been found for the Donetsk low-rank coals, with the correlation coefficients being $R^{2}=0.89-0.95$ (Butuzova, Marinov, Minkova, Safin, Stefanova, \& Stamenova, 2005) (see Figure 1). But the correlation coefficient $\left(R^{2}\right)$ values between the volatile matter yield and the atomic ratio

$\mathrm{S}_{\mathrm{o}}{ }^{\mathrm{daf}} / \mathrm{C}^{\mathrm{daf}}$ fall down up to 0.35 for the middle rank coal. At the same time the correlation between $\mathrm{S}_{\mathrm{o}}{ }^{\mathrm{daf}} / \mathrm{C}^{\mathrm{daf}}$ and thickness of plastic layer (y) appears at this coal rank. 

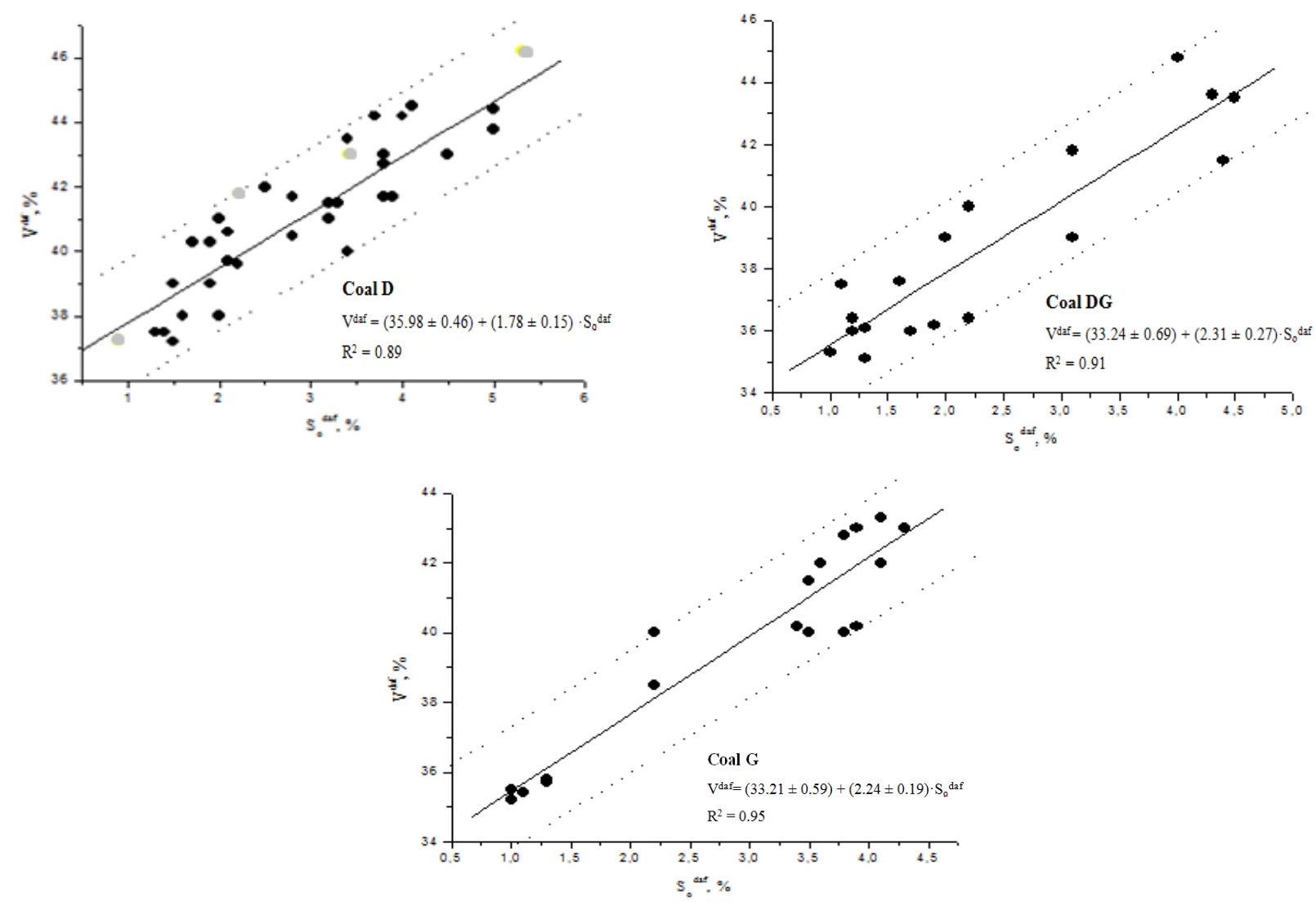

Figure 1. Dependence of the volatile matter yield on the organic sulphur content for low-rank coals.

Then some groups of samples with different ranges of $\mathrm{O}^{\mathrm{daf}} / \mathrm{C}^{\mathrm{daf}}$ values were selected (see Table 2). The correlation coefficients within these groups increase when the interval of $\mathrm{O}^{\mathrm{daf}} / \mathrm{C}^{\mathrm{daf}}$ is narrowing down, i.e., at a more distinct registration of the coal rank.

Table 2

The Variation of Correlation Coefficients Value in Different Intervals of $O^{\text {daf }} / C^{\text {daf }}$ for Middle-Rank (J-Grade) Coals: Atomic $S_{o}{ }^{\text {daf }} / C^{\text {daf }}$ Ratio Versus Volatile Matter Yield (RV-S) and Versus Thickness of Plastic Layer $(R Y-S)$

\begin{tabular}{llll}
\hline Number of coal & Intervals of $\mathrm{O}^{\mathrm{daf}} / \mathrm{C}^{\mathrm{daf}}$ & $R_{V-S}$ & $R_{Y-S}$ \\
\hline 100 & $0.026-0.120$ & 0.35 & 0.64 \\
91 & $0.042-0.093$ & 0.43 & 0.62 \\
62 & $0.050-0.080$ & 0.59 & 0.60 \\
43 & $0.055-0.075$ & 0.58 & 0.61 \\
27 & $0.060-0.070$ & 0.55 & 0.58 \\
22 & $0.050-0.060$ & 0.72 & 0.56 \\
24 & $0.070-0.080$ & 0.61 & 0.68 \\
\hline
\end{tabular}

The influence of coalification degree on the above correlations can be seen also from Table 3, where the range of $\mathrm{O}^{\mathrm{daf}} / \mathrm{C}^{\mathrm{daf}}$ ratio changes in the interval 0.01 for each groups of selected samples. The results show that the correlation coefficient for $R_{Y-S}$ worsen significantly for coals having $\mathrm{O}^{\mathrm{daf}} / \mathrm{C}^{\mathrm{daf}}$ ratio less than 0.1 and for $R_{V-S}$ value the same worsen appears for coals having $\mathrm{O}^{\mathrm{daf}} / \mathrm{C}^{\mathrm{daf}}$ ratio less than 0.05 . 
Table 3

The Variation of Correlation Coefficients Value Versus Coalification Degree

\begin{tabular}{rlll}
\hline Number of coal & Intervals $\mathrm{O}^{\mathrm{daf}} / \mathrm{C}^{\mathrm{daf}}$ & $R_{V-S}$ & $R_{Y-S}$ \\
\hline 8 & $0.10-0.09$ & 0.66 & 0.83 \\
19 & $0.09-0.08$ & 0.55 & 0.67 \\
19 & $0.08-0.07$ & 0.61 & 0.64 \\
22 & $0.07-0.06$ & 0.52 & 0.59 \\
21 & $0.06-0.05$ & 0.72 & 0.56 \\
9 & $0.05-0.04$ & 0.36 & -0.15 \\
\hline
\end{tabular}

An apparent correlation between the $S_{0}{ }^{d a f} / C^{\text {daf }}$ ratio and thickness of plastic layer reflects the effect of sulfur on coal caking ability.

So the theoretical aspects of coalchemistry have not been sufficiently investigated to allow the prediction of the results of coal processing on the base of standard coal characteristics.

As it can be seen from Table 4, the yield of dichloromethane extract is higher for high-sulphur coals in comparison with low-sulphur coals of the same rank, which is indicating an increased solubility of their organic matter.

Table 4

Composition of Extracts Obtained From Coals Under Investigation

\begin{tabular}{|c|c|c|c|c|c|c|c|c|c|c|}
\hline No. & $\begin{array}{l}\text { Coal } \\
\text { grade }\end{array}$ & Type & $\begin{array}{l}\text { Coal mine, } \\
\text { coal seam }\end{array}$ & $\begin{array}{l}\text { Extract yield } \\
\left(\mathrm{CH}_{2} \mathrm{Cl}_{2}\right) \\
\left(\mu \mathrm{g} / \mathrm{g} \mathrm{C}_{\mathrm{o}}\right)\end{array}$ & $\begin{array}{l}\mathrm{C}_{0} \text {, } \\
\text { weight } \\
(\%)\end{array}$ & $\begin{array}{l}\text { Content of } \\
\text { asphaltenes } \\
(\%)\end{array}$ & $\begin{array}{l}\text { Content of th } \\
\text { aromatic } \\
\text { hydrocarbons } \\
(\%)\end{array}$ & $\begin{array}{l}\text { Content of the } \\
\text { aliphatic } \\
\text { hydrocarbons } \\
(\%)\end{array}$ & $\begin{array}{l}\mathrm{N}+\mathrm{S}+\mathrm{O} \\
(\%)\end{array}$ & $\begin{array}{l}\mathrm{S}_{\mathrm{o}}{ }^{\mathrm{daf}} / \mathrm{C}^{\mathrm{daf}} \\
(\mathrm{atm})\end{array}$ \\
\hline 1 & $\mathrm{D}$ & LRC & Cheluskintsev, $1_{4}$ & 10.80 & 76.7 & 59 & 19 & 5 & 21 & 0.0098 \\
\hline 2 & $\mathrm{D}$ & LRC & Trudovskaya, $1_{4}$ & 10.54 & 76.3 & 53 & 12 & 4 & 26 & 0.0041 \\
\hline 3 & $\mathrm{~J}$ & LRC & Gagarina, $\mathrm{m}^{3}$ & 1.88 & 87.8 & 59 & 15 & 13 & 9 & 0.0036 \\
\hline 4 & $\mathrm{~J}$ & LRC & Zasyad'ko, $1_{4}$ & 2.08 & 87.4 & 68 & 17 & 6 & 14 & 0.0026 \\
\hline $1^{1}$ & $\mathrm{D}$ & $\mathrm{RC}$ & Ukraine, $\mathrm{k}_{8}$ & 13.54 & 71.9 & 36 & 24 & 5 & 30 & 0.0105 \\
\hline $2^{1}$ & $\mathrm{D}$ & $\mathrm{RC}$ & Trudovskaya, $\mathrm{k}_{8}$ & 15.77 & 69.0 & 37 & 15 & 6 & 31 & 0.0260 \\
\hline $3^{1}$ & $\mathrm{~J}$ & $\mathrm{RC}$ & Gagarina, $\mathrm{m}_{4}^{0}$ & 2.43 & 87.3 & 53 & 30 & 11 & 12 & 0.0071 \\
\hline $4^{1}$ & $\mathrm{~J}$ & $\mathrm{RC}$ & Zasyad'ko, $1_{4}$ & 2.94 & 83.6 & 64 & 25 & 6 & 14 & 0.0058 \\
\hline
\end{tabular}
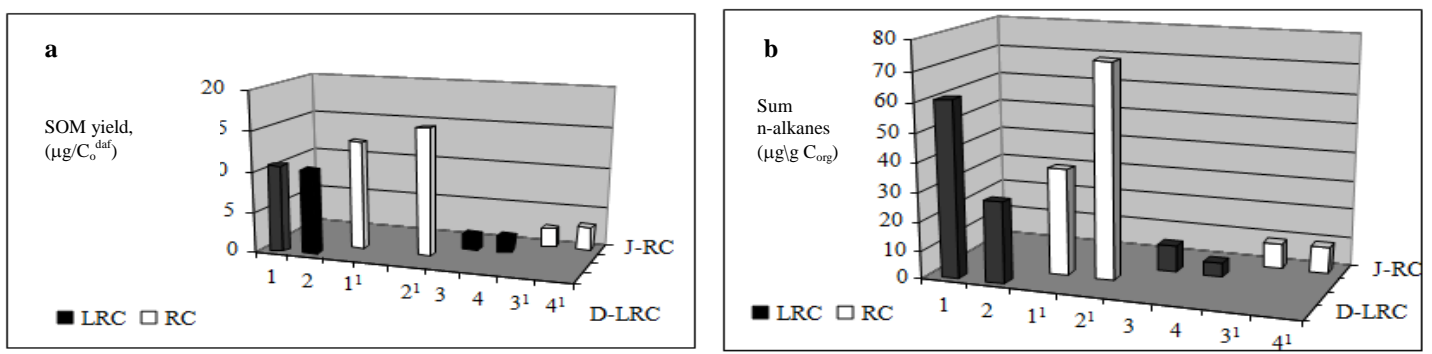

Figure 2. Content of extractable organic matter (a), n-alkanes (b) in extracts of LRC and RC of different coalification degree (D, J).

The extracts obtained from RC coals are characterized by a higher content of polar heterocompounds, as well as aromatic hydrocarbons, which corresponds to their high caking ability. The main part of the extracts of the investigated coals is composed of asphaltenes (36\%-68\%) - highly reactive components. Quantity of asphaltenes is much higher for coals of low-reduced type. Obviously, their segregation at the early stages of thermal decomposition is very important for the formation of plastic layer and subsequent formation of the coke structure. 
Gas chromatography - mass spectrometry analysis of aliphatic and aromatic fractions of the extracts revealed significant quantitative differences in the composition of components extracted from different coals.
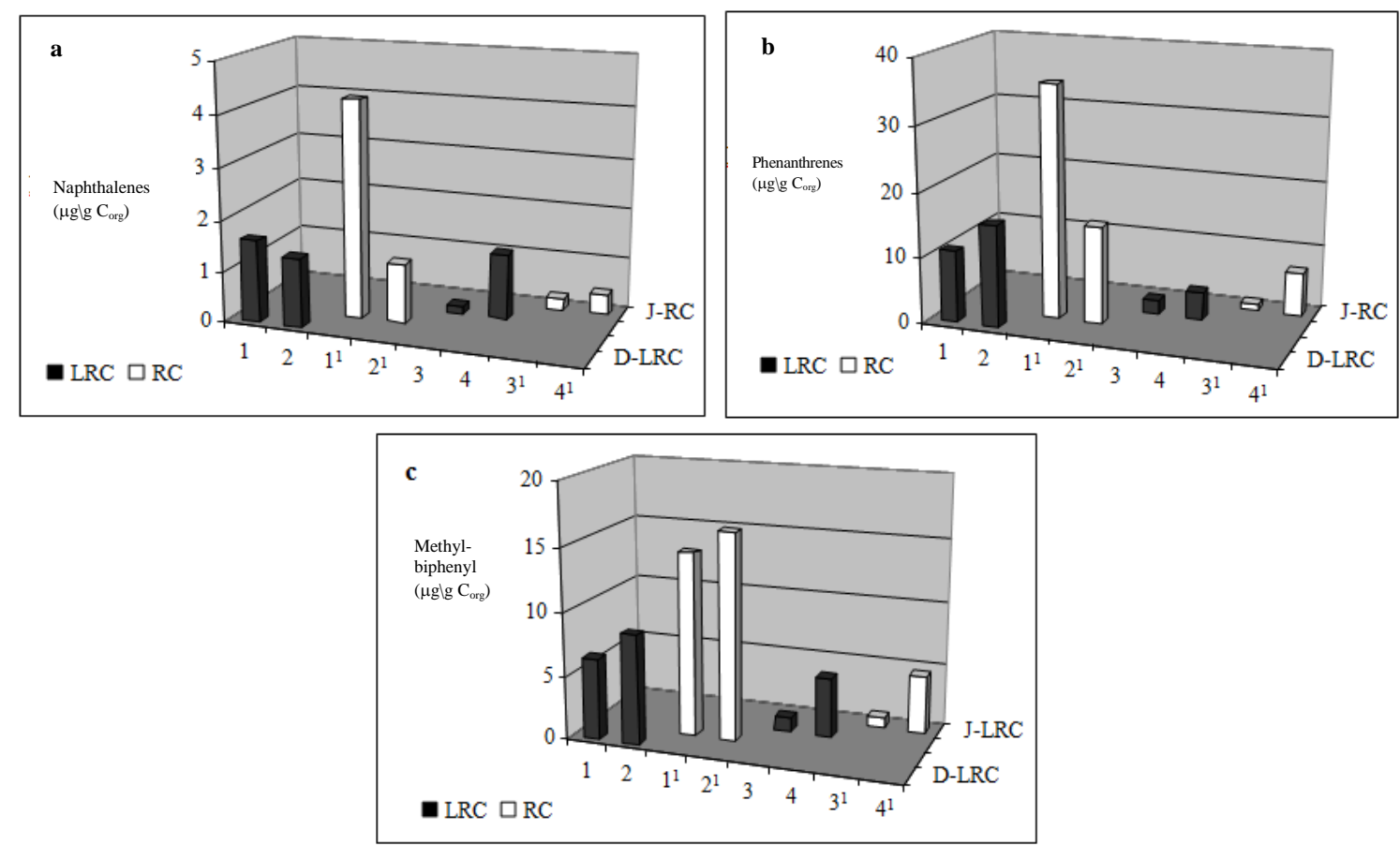

Figure 3. Content of Naphthalenes (a), Phenanthrenes (b), and Methyl-biphenyl (c) in extracts of LRC and RC of different coalification degree (D, J).
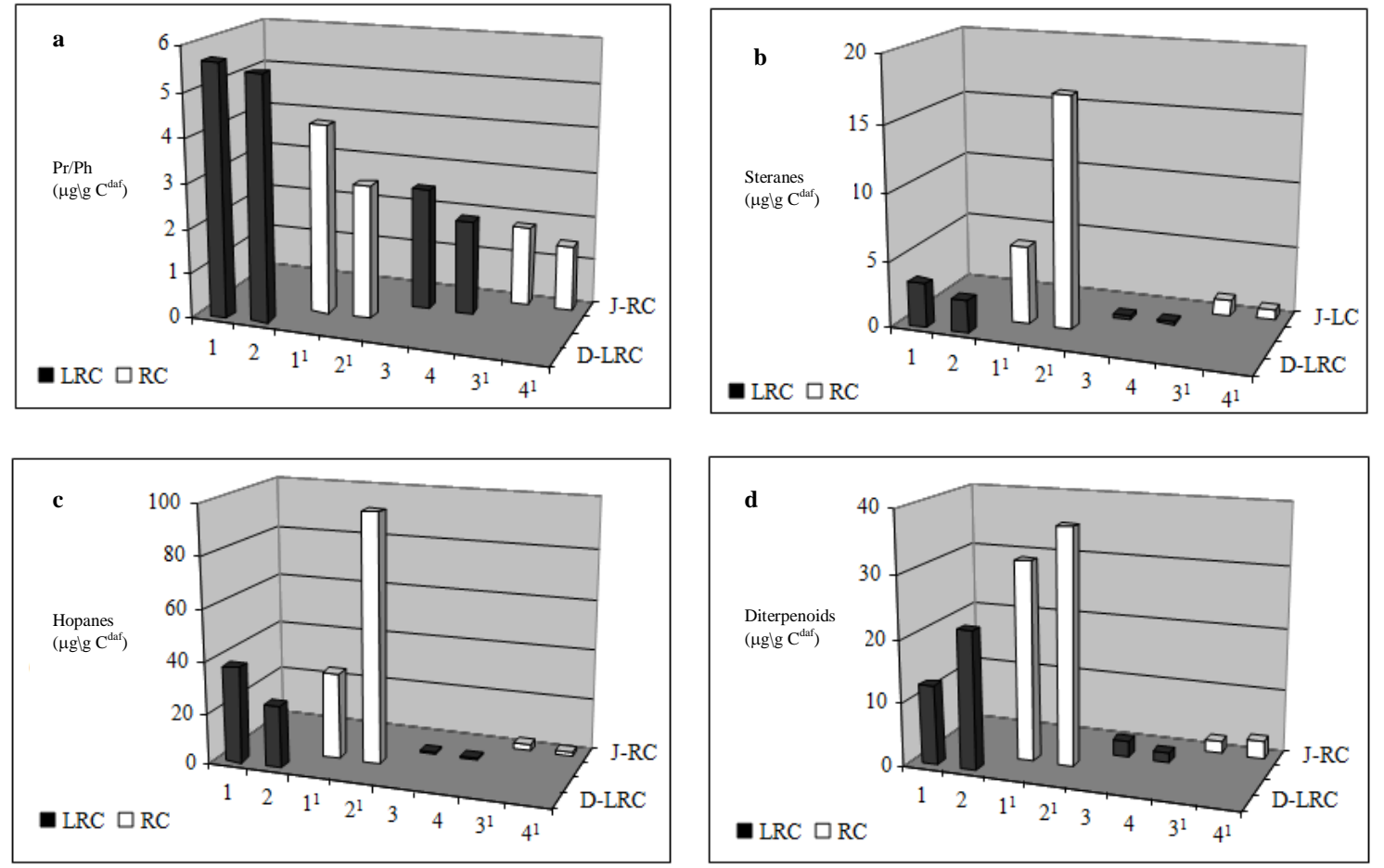

Figure 4. Content of Pr/Ph (a), Steranes (b), Hopanes (c), and Diterpenoids (d) in extracts of LRC and RC of different coalification degree $(\mathrm{D}, \mathrm{J})$. 
A sharp decrease in the yield of the dichloromethane extract (Figure 2a) and in the concentration of the following components of hydrocarbons is observed during the transition from the low-rank to middle-rank coals:

- $n$-alkanes (in 6-9 times) (see Figure 2b);

- aromatic compounds, such as naphthalenes, phenanthrenes, biphenyls, and their alkyl-substituted derivatives, especially methyl-substituted (see Figure 3);

- biomarkers - the pristanes, phitanes, steranes, hopanes, and deterpenoides (see Figure 4).

$n$-alkanes with shorter chain $\left(\mathrm{C}_{15}-\mathrm{C}_{19}\right)$ dominate in J-Grade coals, whereas the long-chain alkanes $\left(\mathrm{C}_{27}-\mathrm{C}_{31}\right)$ dominate in extracts of D-Grade coals. The results are in agreement with existing concepts about the reduction of the proportion of long-chain alkanes during coalification.

Reducing the quantity of 2-3-ringed aromatic compounds in the extract is accompanied by the appearance of polycyclic aromatic compounds (see Figure 5a). This fact is evidence that highly-condensed aromatic structures are formed during the processes of aromatization at the metamorphism. Some of them go into an insoluble state.

The study of the hydrocarbon fractions of RC and LRC extracts showed a significant difference in the quantity of oxygen and sulfur-containing compounds. An absolute content of dibenzothiophenes (0.94-20.34 $\left.\mathrm{g} / \mathrm{g} \mathrm{C}^{\mathrm{daf}}\right)$ is significantly higher in high-sulphur samples in comparison with low-sulphur $\left(0.83-9.09 \mathrm{~g} / \mathrm{g} \mathrm{C}^{\mathrm{daf}}\right)$ as well as the content of oxygen-containing dibenzofuran (see Figures $5 \mathrm{~b}$ and $5 \mathrm{c}$ ).

Steranes identified in the studied extracts have 27-29 carbon atoms. Steranes $\mathrm{C}_{29}$ are dominate. Their presence indicates the influence of higher terrestrial vegetation (Jauro, Obaje, Agho, Abubaker, \& Tukur, 2007). The concentration of steranes is higher for reduced samples. Especially, a sharp increase of the $\mathrm{C}_{27}$ steranes content is observed for reduced coals (in 5-7 times).

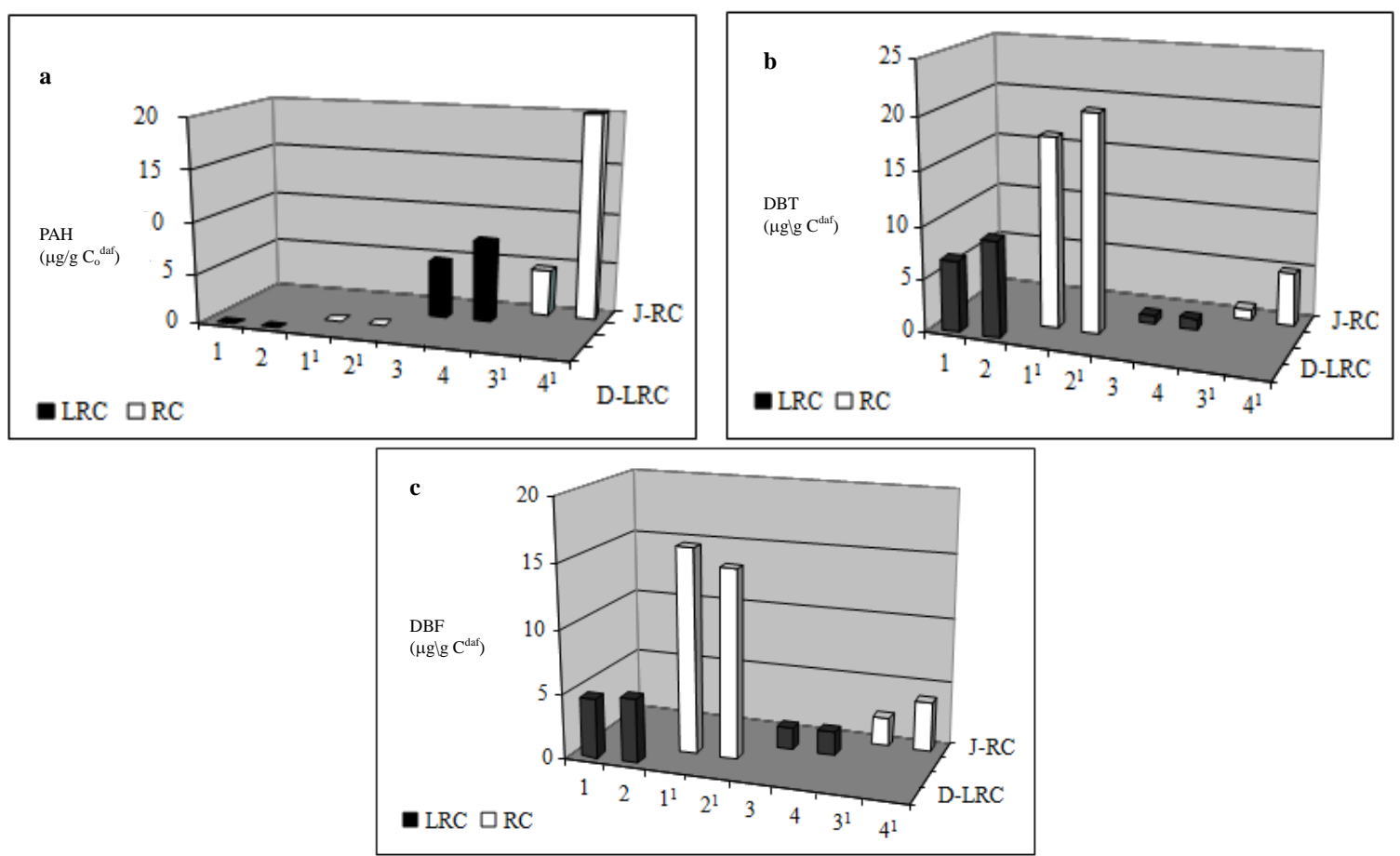

Figure 5. Content of PAH (a), dibenzothiophene (b), and dibenzofuran (c) in extracts of LRC and RC of different coalification degree (D, J). 
Extracts of J-grade reduced coals differ from LRC extracts by significantly higher content of hopanes, including stereochemically converted, so-called oil-hopanes, with a higher thermodynamic stability $(\alpha \beta$ configuration). The change in the configuration of the aliphatic chain $(22 \mathrm{R} \rightarrow 22 \mathrm{~S})$ is greater for the samples of reduced type, which is consistent with a high bacterial activity during marine transgressions. The higher steranes/hopanes ratios in this case indicate high primary productivity during sea level rises.

Phytane $(\mathrm{Ph})$ and Pristane (Pr) are often regarded as products of reduction or decarboxylation of phytol, a component of chlorophyll, cyanobacteria diphytilovyh esters, some algae and landed shellfish. Typically, the ratio of $\mathrm{Pr} / \mathrm{Ph}<1$ is used as a marker of reductive conditions of diagenesis, and $\mathrm{Pr} / \mathrm{Ph}>1$ for oxidation conditions (Waples \& Machihara, 1990).

The calculated $\mathrm{Pr} / \mathrm{Ph}$ ratio characterizes a more reducing environment during the organic matter transformation of RC coals.

Influence of sulphur content in coal on the yield and composition of the extracts was evaluated by changes of various characteristics of the extracts, depending on the atomic ratio $\mathrm{S}_{\mathrm{o}}{ }^{\mathrm{daf}} / \mathrm{C}^{\mathrm{daf}}$. A clear correlation between the declared value and the proportion of S-containing rings in the total quantity of aromatic rings was detected (see Figure 6a). This correlation is better for the coals of the middle rank $\left(R^{2}=0.99\right)$. The ratio $\mathrm{S}_{\mathrm{o}}{ }^{\mathrm{daf}} / \mathrm{C}^{\mathrm{daf}}$ perfectly correlated with the relative content of hopanes (see Figure 6b), so, with high microbial activity during sea transgression.

Based on the distribution of various classes of compounds in the extracts of high- and low-sulphur coals, it can be seen that the ratio $S_{0}{ }^{d a f} / C^{\text {daf }}$ in coal (see Figure 6), the extraction yield and the contents of hopanes, biphenyls, dibenzofurans, and dibenzothiophenes can be used as chemical indicators of coal ability to environment pollution with carcinogenic products.

The yield of biphenyls from coal extracts was found to correlate with coal pyrolysis tar yield. So, this structural parameter is very important index for evaluation of coal environment pollution.

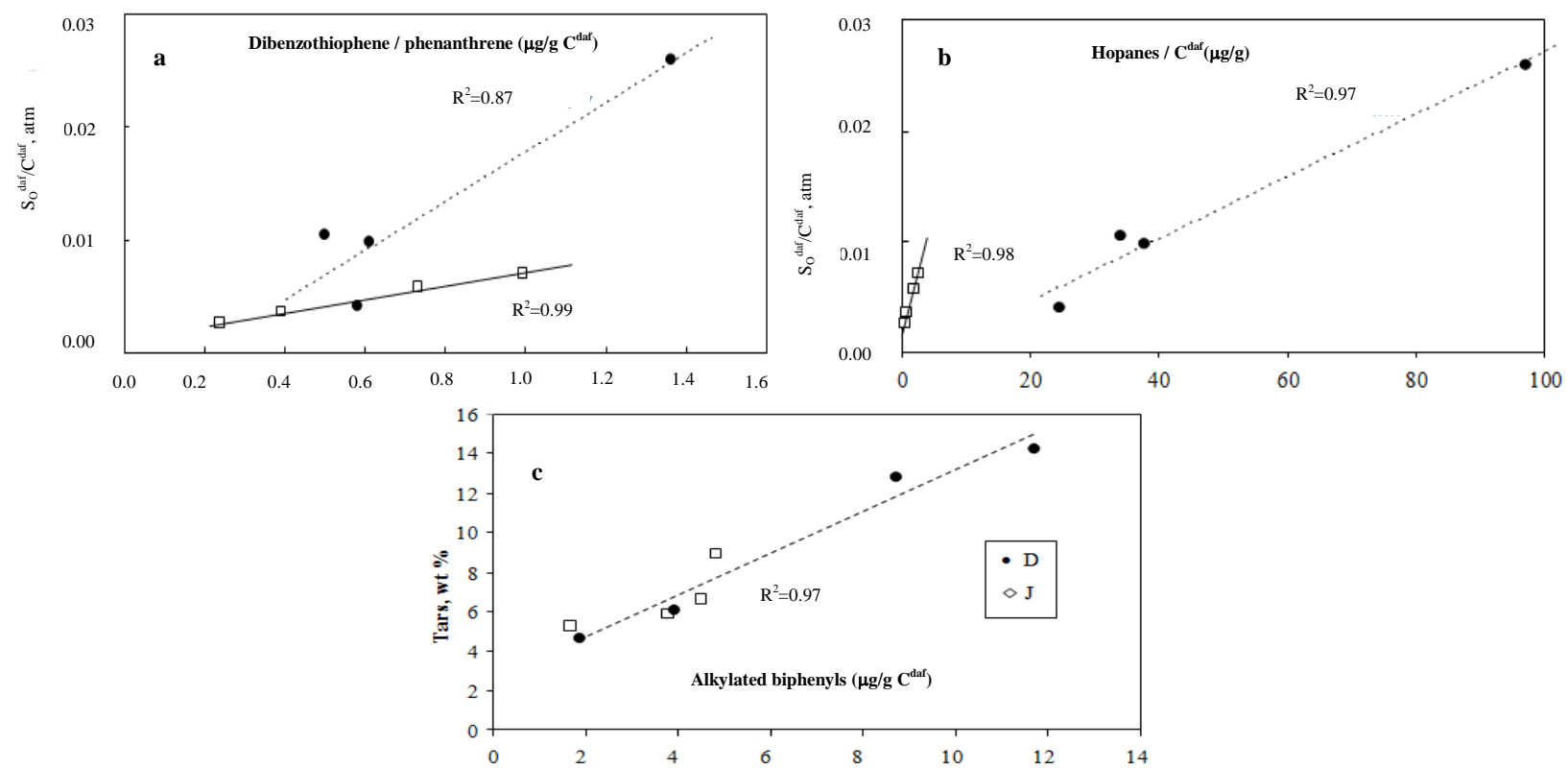

Figure 6. Different correlations for the studied coals: (a) atomic $\mathrm{S}_{\mathrm{o}}{ }^{\mathrm{daf}} / \mathrm{C}^{\mathrm{daf}}$ ratio versus dibenzothiophene/phenanthrene contents, (b) atomic $\mathrm{S}_{\mathrm{o}}{ }^{\text {daf }} / \mathrm{C}^{\text {daf }}$ ratio versus hopanes content, and (c) yield of tars versus alkylated biphenyls. $\mathrm{S}_{\mathrm{o}}=$ organic sulphur. 


\section{Conclusions}

From the perspectives of the paper, we can conclude that:

(1) Obtained results indicate the connection between vapour organic products emission, i.e., yield, composition of extractable organic matter and sulfur content in coals;

(2) Appearance of polycyclic aromatic hydrocarbons in the coking coals extracts, increase of the biphenyl, DBT and DBF content for RC may apply for assessment of the technological properties of coals for their rational use;

(3) The least polyaromatic compounds emission is produced from low quality sulphur coals.

Therefore, we believe that due to its abundance coal is truly an important energy source and a very versatile organic material, but it is a heritage that has special necessities, its usage and byproducts are a problem that ought to be seen from a sustainable perspective.

\section{References}

Bechtel, A., Butuzova, L., \& Turchanina, O. (2002). Thermochemical and geochemical characteristics of sulphur coals. Fuel Processing Technology, 77-78, 45-52.

Butuzova, L. (2004). Agglutinated materials from low-rank sulfur coals. Proceedings from 3rd International Conference "New Carbon and Composite Materials 2004”. Ustrone Zawodzie, Poland.

Butuzova, L. F., Marinov, S., Minkova, V. N., Safin, V. A., Stefanova, M., \& Stamenova, V. (2005). Pyrolysis of low-reduced and reduced coals of different rank. Bulletin of Geosciences, 80(1), 15-18.

Butuzova, L. F., Minkova, V. N., Safin, V. A., Marinov, S., \& Stamenova, V. (2005). Adsorbents from sulphur coals of the coal rank. Polish Journal of Environmental Studies, 14(IV), 75-79.

Butuzova, L. F., Rozhkov, S. P., Makovskyi, R. V., Rozhkova, N. N., \& Butuzov, G. N. (2009). The contribution of radicalreactions during thermal processing of low-quality coals. Geolines, 22, 9-14.

Butuzova, L., \& Krzton, A. (2001). About mechanism of soft coal pyrolysis. Acta Universitatis Carolinae-Geologica, 45(2-4), 23-25.

Butuzova, L., Bechtel, A., Turchanina, O., Safin, V. A., Butuzov, G., \& Isaeva, L. (2005). Organic sulphur as a main index for determining the genetic type of low-rank coals. Bulletin of Geosciences, 80(1), 3-8.

Butuzova, L., Isaeva, L., Turchanina, O., \& Krzton, A. (2002). Thermodestruction of brown coals of different genetic types. Fuel Processing Technology, 77-78, 145-150.

Butuzova, L., Krzton, A., Saranchuk, V., \& Isaeva, L. (1994). Influence of oxygen on the behaviour of oxygen-containing groups of soft coal in pyrolysis. Fuel, 73(6), 945-950.

Butuzova, L., Makovsky, R., Butuzov, G., Isaeva, L., Shevkoplyas, V., Bulyga, O., \& Jankowska, A. (2007). Opportunities of waste plastic recycling during semi-coking and coking processes. Proceedings from 11th Conference on Environment and Mineral Processing \& Exhibition. Ostrava, Czech Republic.

Butuzova, L., Safin, V., Marinov, S., Yaneva, N., Turchanina, O., \& Butuzov, G. (2009). The pathways for thermal decomposition of coals with high content of sulphur and oxygen. Geolines, 22, 15-19.

Jauro, A., Obaje, N. G., Agho, M. O., Abubaker, M. B., \& Tukur, A. (2007). Organic geochemistry of Cretaceous lamza and Chikila coals upper Benue trough, Nigeria. Fuel, 86, 520-532.

Lavrieux, M., Jacob, J., LeMilbeau, C., Zocatelli, R., Masuda, K., Breheret, J., \& Disnar, J. (2011). Occurrence of triterpenyl acetates in soil and their potential as chemotaxonomical markers of Asteraceae. Organic Geochemistry, in press.

Marinov, S., Minkova, V., Stefanova, M., \& Butuzova, L. (2000). Comparative study the effect of two treatments on sulphur types distribution in coal. Acta Montana IRSM AS CR Series B, 10(117), 27-35.

Mastral, A. M., Callen, M., \& Garcia, T. (2000a). Toxic emissions from coal combustion. Fuel Processing Technology, 67, 1-10.

Mastral, A. M., Callen, M., \& Garcia, T. (2000b). Benzo(a)pyrene, Benzo(a)anthracene and Dibenzo(a, h)anthracene Emissions from coal and waste tire energy generationat atmospheric fluidized bed combustion. Environ. Sci. Technol., 35, $2645-2649$.

Mastral, A. M., Callen, M., Garcia, T., \& Lopez, J. (2000). Fluidized bed combustion of fossil and nonfossil fuels: A comparative study. Energy and Fuels, 14, 275-281. 
Mastral, A. M., Callen, M., Murillio, R., Garcia, T., \& Vinas, M. (1999). Influence on PAH emission of the air flow in AFB coal combustion. Fuel, 78, 1553-1557.

Minkova, V. N., Butuzova, L. F., Marinov, S., \& Safin, V. A. (2004). Adsorbents from sulphur coals of the coal rank. Proceedings from 10th Coal Geology Conference. Prague, Czech Republic.

Petersen, H. I., \& Nytoft, H. P. (2006). Oil generation capacity of coals as a function of coal age and aliphatic structure. Organic Geochemistry, 37, 558-583.

Stach, E., Mackowsky, M., Teichmüller, M., Taylor, G. H., Chandra, D., \& Teichmüller, R. (1975). Coal petrology. Berlin-Stuttgart: Gebrüder Borntraeger.

Taylor, G. H., Teichmüller, M., Davis, A., Diessel, C., Littke, R., \& Robert, P. (1998). Organic petrology. Berlin-Stuttgart: Gebrüder Borntraeger.

The Donetsk Coal Chemistry Research Institute. (1972). The catalogue of the Donetsk and Lviv-Volyn basins black coals and anthracites quality (p. 168). Moscow: NEDRA.

Waples, D. W., \& Machihara, T. (1990). Application of sterane and triterpan biomarkers in petroleum exploration. Bulletin of Canadian Petroleum Geology, 38(3), 357-380. 